International Journal of Multi Disipline Science (IJ-MDS)

e-ISSN: 2615-1707 DOI: http://dx.doi.org/10.26737/ij-mds.v1i1.437

\title{
Role of The Local Government in The Preservation Wadian Dadas of Ritual in The East Kalimantan Barito Regency of Central Province
}

\author{
Effrata $^{1}$, Tresia Kristiana ${ }^{2}$ \\ PGRI University Palangkaraya, Indonesia ${ }^{1}$, Christian University Palangkaraya, Indonesia ${ }^{2}$ \\ effrata1970@mail.com ${ }^{1}$, tresiakristiana@yahoo.co.id ${ }^{2}$
}

\author{
Keywords : \\ The Role of \\ Government, Wadian \\ Dadas
}

\begin{abstract}
This research is about the role of local government in the effort to preserve the cultural customs that exist in the life of the Dayak people who Ma'anyan live in areas along the Barito river in East Barito regency. Wadian Dadas is one of the means of ceremonies in the field of traditional medicine in Ma'anyan Dayak tribe community in Central Kalimantan Province. That said, Wadian dadas originally Obtained through the inspiration Obtained by a woman named Ineh Ngundri Mountains. The woman is inspired to perform the duties of a god to heal a person or what is commanded by God. This woman is the first Wadian and is a messenger of gods embodied in the form of an eagle, then Wadian will be continued by the next Descendants. This study used descriptive qualitative method. Data collection techniques were conducted by primary and secondary collecting the data through interviews and observations with resource persons, for secondary Data Obtained from history books and documents belonging to the village government. The results Showed that Wadian Dadas originally for the healing rituals of the sick who started with the preparation of offerings, to perform the healing ritual by involving Wadian (shaman) is very trusted by the Dayak community Ma'anyan. Wadians in Ma'anyan Dayak community have now developed into Wadian Dadas Dances. Dadas Wadian dance begins with dances performed in the process of traditional medicine performed by Wadian. In the early 1980s Wadian dadas was known by some so that Wadian dadas the which originally served as a ritual ceremony medication Became an inspiration for the appearance of the dance Wadian Dadas. Dadas Wadian dance is one of the traditional dances. This dance is unique in its simple and energetic motion, the which has deep meaning and is Often presented in traditional events of Central Kalimantan. In the beginning this dance is performed with the excuse to get healed and free from evil spirits cause disease. The findings of this study are as the times progress, this dance is also presented at the event of welcoming and marriage. But there are still many people of Indonesia, even the citizens of Borneo who have not understood and are reluctant to desire to preserve this traditional dance. Dadas Wadian magical dance contains high value Because in every movement contains meaning, even in movement there is a spell pronunciation.
\end{abstract}




\section{INTRODUCTION}

Along with the development and the changing times Dayak culture also experienced a shift, due to the inclusion of elements outside influence. This means that the nature of the Dayak culture is not static and is always dynamic; however, until now there are still survive and unshaken by the alternation of generations, and even more to show his identity as a heritage. Customs community, rituals and celebrations. Knowledge and practices concerning nature and the universe's behavior; such as traditional medicine, is one of the local wisdom that still survive are Wadian Dadas. Wadian Dadas is one means of ceremonies in the field of traditional medicine in society Ma'anyan Dayak in Central Kalimantan province. Wadian Dadas was originally obtained by the inspiration derived by a woman named Ineh Ngundri Mountains. The woman was inspired to run a task from a god to cure someone of this woman is the first Wadian and the messenger god embodied in the form of an eagle, then Wadian will be forwarded by the subsequent descent.

\section{METHOD}

This study aims to preserve indigenous culture as local wisdom that must be maintained by the community through the role of local governments. To solve the problems that occur study was conducted with observation (observation), in-depth interviews, interaction, and seek to understand, to the subject and object of research so that they could understand the government's role in preserving the indigenous culture of the Dayak community, especially in the development Wadian Ma'anyan Dadas of Ritual healing into the Regional Dance of Dayak Ma'anyan.

\section{RESULTS AND DISCUSSIONS}

Wadian is one of the traditional ceremoniestribe of the Dayak village, Maanyan, embracing Kaharingan of them in order to cure thesick. Days of yore, when the treatment is not as advanced as today, the Dayaks Maanyan utilize the services Wadian to treat pain they suffered. Old or not the ritual of treatment depends on the severity of the illness, Wadian ceremony can be held for 1 (one) week more. Wadian types include: Wadian Pangunraun (Pangunraun Fall, Pangunraun Java), Wadian Dapa, Wadian Tapu Unru, Wadian dadas, Wadian Bawo, Wadian round.

Wadian Dadas is a ceremony to cure diseases. Hospitals in this definition is that if someone was troubled with his health. In the ritual healing ceremony performed by the fulfillment of the requirements of ritual form: (1) sangku dite is sangku containing white glutinous rice; (2) Sangku Lungkung is sangku containing berasw; (3) Sugar Round, Round Niuy is a pack of brown sugar, one coconut fruitround; (4) Babuang Tatungkal sangku containing coconut milk and woven palm leaves called Tatungkal; (5) variety Pasiwahan are four plates Papacy (ceramic plate); (6) fabrics Pasiwahan is a long cloth or cloth gloves were placed over a wide pasiwahan; (7) quests Wood placed on a variety of pasiwahan; (8) Sculpture also placed on a variety of pasiwahan; (9) Tabingkar Kalanis ashes or embers put in the pot then there bakam ilau (coconut oil is placed in a variety of pasiwahan).

The ritual or ceremony Wadian Dadas which consisted of the following:

a. Ngilau Weah Nurun Master

A ceremony that was started by seoarang shaman by taking a pinch of rice contained in a variety of pasiwahan placed on the left hand, then a dash or a drop of coconut oil rubbed keberas and sprinkled into embers, At the time ngilau weah descending teachers implemented then reda the magic which reads as follows:

I ngilau hanyu weah ngalanis wunge epidemic, fear weah Sampa weah oath, weah pitulur weah pahidang Luwan weah ina kahante nwatang tenga karandrung pakun Lunuk Luwan let me amas maeh carefree silaka piue Salu face-pounding divorce naman damya Wusi weah I entered graduate manguru mangaji. 
b. Isiwah

Ceremony was held for the cleaning of the evil spirit that seems to be jinxed or heartbreak, this is done when the group comes either from afar or up close. The ceremony began with menangankat Variety Pasiwahan with his left hand parallel to the heads of crowds or guests then recited a mantra which reads:

Luwan ina naan variety pasiwahan, naan tamayang patibasan, naan fabric pasiwahan Sinyang patabasan wear mawah antupadi, antuliun, antutungkan, antutangis, Antu raring puzzle pangupahan upi, pangaruning lule, puzzles penampekan uwei pamirisan luluk lai, puzzles sightings telang eldest pemirisan.

c. Natungkal

Coconut water sprinkling ceremony stored in sangku that uses tatungkal (woven coconut leaves). This ritual is performed by reading the following incantation:

I natungkal wearing a sky kupang ranu uma ngalulayang anrau ranu Jahun katinawung enu Tutung germs manta ranu singkai wari wari uma talunyangan gambling. Ranu singkai-wari wari uma talunyangan nyawung ranu accomplished accomplished revere the king upus ranu wunge marisak tray puzzle mareke maali malimun marisak ranu putut frightening. Wayu rirung lalir katuluhan kajarahan matakam parlors.

d. Nguriak Amirue

Pinch of rice in wide pasiwahan taken with the right hand then sprinkle to invite as pick form the spirit of the living in order to avoid various diseases. The sound of magic is recited as follows:

1. Host Host Weah Karupiti Ata Ina Itak, Fur Amirue Mudi Kala Wuang Hunang. Salalungan Mantuk Diang Wauah Alap.

2. Karupitu Host Host Inan Teu Amirue Mudi Kala Wuang Hunang. The logic of Alang Wuah Salulungan professor, Ma Mudi Uras Watang Tenga, Fur Ma Pakun MUNIK Mantu.

e. Tatang Ngape Amirue

Sculpture or knife or lading as a substitute for, existing in a variety pasiwahan kepalaq pulled up parallel to the invitation (the crowd) with a view to strengthen the spirit that has been picked up in the event Nguriak Amirue. The magic read reads as follows:

Kape jatang amirue teah itak hang watang umung sky tenga rigup uluh legar Tane henna Rahan. Wui nerve rahann jatang kalelu germs executor nguri Kabali, executor steel Hansur Lalan Ruya hang iwa mountain jatang hang uти mountain immediately hang uти mountain immediately hang ити mountain amirue rank watu salulungan amirue takam piduk rumung rama salulungan Ipah bawai bahai

Wadian Dadas This is usually done by Dayak shaman woman to ask for healing to Ranying Hatala Heaven (God). Dadas Wadian name itself is taken from seutan shaman women, which in the Dayak community called balean Dadas. In dance Wadian necessary preparations Dadas dances are:

1. Dance Preparation Tool

a. Gong (grand) which amounts to two. The gong is used as a tool unique sound of the dance Tribe Maanyan Southwestern Wadian dadas. The gong is sounded alternately to cause noise typical in mulung Kuyang summon spirits. The gong is made of brass (Ganza) to compensate for kangkanung sound.

b. Kangkanung five fruit. Kangkanung an instrument sound as a counterweight of the sound of a gong. Kangkanung is a kind of instrument that is also found in Java. Kangkanung has a size of $20 \mathrm{~cm}$ and has a bulge at the top, the tone of each kangkanung produced from thick tips each fruit kangkanung, the tone A, C, D, E and $\mathrm{G}$ with classification tone pentatonic.

c. Drum (Gandrang Tebung/ketipung) musical instruments which is emitted by being hit, the usual dimaukan by hand or withbat.

2. Tools Wadianin carrying out the ritual of healing diseases. Wadian (Balian) Dadas require a special device in the form of:

a. Taringit (Headbands) made of palm leaves and twine. Headbands are made of palm leaves are commonly used for ritual healing of severe disease. Headband made of yarn for common diseases. Headband worn by Wadian indicates the severity of the disease suffered by people for healing. 
b. Skelter Jandam (Belt) made hollow brass such as a belt or a pending commonly used to tie a sarong/kuwing worn by Wadian dadas in implementing the spirit summoning ritual Kuyang mulung. Skelter Jandam useful as a belt for dancers Wadian dadas to keep the sarong or kuwing used by Wadian dadas time of execution of the dance does not sag, because at the time of the ritual performed dancer Wadian dadas if already possessed Kuyang mulung dancers can not act normal due to the influence of spirits Kuyang mulung that already dominate the sport the Wadian dadas.

c. Kuwing (Gloves), which is used Wadian dadas or dancers as subordinate or gloves. Holsters make sense that a sacred dance dadas Wadian. Sacred because before being implemented ritual dance is performed by swinging the reading spell kuwing cloth (sarong). Kuing or bahalai at the dancers wear the bracelet healers dadas of age.

d. Kutang clothes, clothes worn dadas or Wadian dadas dancer who just closed the chest part of the dancer. Clothes Brassiere is like a breastplate that women wear, shirt bra sewn solely by healers Wadian dadas, clothes camisole looks beautiful because of stitches in the size of the body of a shaman Wadian dadas, made of rope or fabric, sewn neatly so it's compatible with kuwing (sheath) that they wear at the time of execution ritual.

e. Wadian bracelet Dadas, the shaman or bracelet worn on the wrist Wadian left and right, with the number 34 left hand right hand, four left and five right, five left and six right. Bracelet worn rhythms cause sounds to match the drum beating.

f. Tenrek is Whiting smeared on the face and hands Wadian dadas, Tenrek on the face indicates a balian dadas, Tenrek the left arm or right when Balah sangarnya have three points below that of a shaman dadas it has three subordinate (child amu) If it is below bala frightening no dot means balian dadas not had amu pupil or child, as the healers not having magic and special abilities.

Wadian before carrying out the rituals also have to set up equipment in the form of offerings that will be recited incantations as a tool in the implementation of the Ritual Wadian Dadas.dadas The equipment for ritual offerings in Wadian dadas are varying degrees of pus, which contains a bowl, a place to store the entire offerings named Tabak. A means to store offerings generally consist of:

1. Bowl Mansi / Bowl Junyung made of glass which contains: Empak (whiting, gambier, areca nut), tipak Pisis milled nut (cane shaped like a coin one cent), taringit (rawen wundrung or leaf coconut), rawen kamat (leaf sawang), antelui (egg), candles. Mansi bowl or bowl Junyung during Wulung Kuyang spirit summoning ritual.

2. Pus (nyiru) is a store of offerings that are made of rattan, a place to store the contents of offerings that consists of: dite (white glutinous rice), lungkung (rice), Damuk (where oils are used healers in curing the disease, salumpayang (whistle made of tusk bears).

3. Other Fittings in fulfillment treatment equipment comprising: Pakinkin or known lamang/lemang (glutinous rice cooked in bamboo), banana leaf spot save ampatung sarah themselves (statues of women and men made of flour sticky rice), manu manru (chicken cooked with boiled without seasoning), kaluwit (cake/pais made from glutinous rice), cloth madintang (cloth colored yellow), fabric maintem (black cloth), glutinous rice (weah dite) and rice lungkung.

Upon fulfillment of the requirements for Wadian dadas include the ritual can begin by starting a dance that uses the style or swing swing like: swinging bahalai, ngarungkum, nyajah, maningkah / grip, mengamet, anipei, ngampamai pujat, miusat.

Wadian Dadas, originally a ritual of healing diseases existing in Ma'nyaan Dayak people who practice faiths Kaharingan in antiquity, has now changed. Wadian Dadas already known as Dance Bracelet Wadian Dadas. Dadas Wadian Bracelet dance that originated from a healing ritual dance is now welcoming a special guest or invited by the local government, and dance Wadian held a wedding ceremony or fulfillment Indigenous customary law in a ceremony wedding Ma'anyan Dayak community. Dadas Wadian dance or dance known as the Dadas existing Gelang Wadian on Ma'anyan Dayak community is still used by the community for the healing of certain diseases can't be treated medically. 
Dadas Wadian dance has also been developed that is used in a welcoming ceremony and a traditional marriage ceremony, especially in full of customary law, therefore, the regional government should participate in the preservation of dance Wadian Dadas, meaning demanded the government's role to help preserve the culture of dance Wadian Dadas. The local government in this case is the local government according to Law No. 32 of 2004 the Governor, Regent, or Mayor, and the region as an element of the regional administration. While the local government according to Law No. 32 of 2004 is the implementation of government affairs by the local government and parliament according to the principle of autonomy and duty of assistance with the principle of autonomy width in the system and the principles of the Republic of Indonesia as stipulated in the Constitution of the Republic of Indonesia Year 1945.

Role Governments in the dance Wadian Dadas in East Barito especially Ma'anyan Dayak community can be preserved by involving healers and dancers Wadian dadas on cultural events and tourism activities. In an effort to boost tourism growth and achieve the goal of tourism development, the necessary management and development of a tourist attraction. Namely tourism management planning efforts, implementation, and monitoring of natural and cultural potential by taking into account aspects of preservation. Tourism requires management concepts or scientific management and modern marketing. Management includes five basic elements, namely, organizing, planning, motivation, personal and drive placement, coordination and supervision.

In an effort to boost tourism growth and achieve the goal of tourism development, the necessary management and development of a tourist attraction. Namely tourism management planning efforts, implementation, and monitoring of natural and cultural potential by taking into account aspects of preservation. Tourism requires management concepts or scientific management and modern marketing. Management includes five basic elements, namely, organizing, planning, motivation, personal and drive placement, coordination and supervision.

\section{CONCLUSION AND SUGGESTION}

Based on the formulation of the problem, and the results of research and discussion on the role of the Government in preserving Ritual Wadian Dadas in East Barito Regency, Central Kalimantan Province city of Palangkaraya, it can be concluded the following:

1. Wadian Dadas was originally a ritual of healing diseases in indigenous communities Dayak Watershed Ma'anyan in Barito, a healing ritual was first performed by Ineh Ngundri Mountains.

2. Dadas Wadian implemented with special requirements such as compliance offerings that have been determined, in a ceremony conducted special incantations readings by Wadian.

3. In any event there Wadian ritual dance music which is accompanied wasp drums and sounds of bracelets Wadian dadas.

4. Wadian Dadas has evolved from ritual cures Ma'anyan Dayak became a dance at the time of the marriage ceremony or the reception of important guests from the local government.

\section{REFERENCES}

Budhisantoso, S. (1991). The style of Indonesian Culture. Indonesian Studies, 1: 11-62. Durrenberger.

Bobin, $\mathrm{AB}$ et al (eds). Monographs Regional Central Java. Jakarta: Dept. of Culture Media Development Project P \& KRI.

Encyclopedia of Cultural Anthropology, Volume 1, (Eds. David Levinson and Melvin Ember), New York: Henry Holt and Co., 1996, pp. 309-312.

Geertz, H. (1981). Arts, Culture and Community in Indonesia. Jakarta: Foundations of Social Sciences.

Giddens, A. Structuration Theory (Basics Community Social Structure Formation): Jakarta

Harris, M. (1999). Theories of Culture in Postmodern Times. New York: Altamira Press. Istadiyantha, 2009."Theory Task Text". Yogyakarta: Graduate School of Gadjah Mada University.

Koentjaraningrat. (1974). Introduction to Anthropology. Jakarta: New Script. 
Kunst, J. (1973). Music in Java: its History, its Theory and its Technique The Hague: M. Nijhoff (2 vols).

Literary Sciences Magazine Indonesia (Indonesian Journal of Cultural Studies), June volume X number 1. Jakarta: Faculty of Letters, University of Indonesia.

Marzali, A. (1997). "Preface". In James P. Spradley, Ethnographic Method (Translation). Yogyakarta: Tiara Discourse, p. Xv-xxiii.

Masinambow, Koentjaraningrat and Anthropology Indonesia. Jakarta: Yayasan Obor Indonesia and Indonesian Anthropological Association, p. 93-104.

Melalatoa, J.M. (1997) "Ethnographic Study of Development in Indonesia". In EKM Parto, Suhardjo. 1990. On Traditional Dances of Indonesia (Unpublished Paper) originally submitted to Performing Arts International, Gordon and Breach.

Paul, E. (1996). Ethnography. In Encyclopedia of Cultural Anthropology (Volume 2). New York: Henry Holt. p. 416-422.

Raho, B. (2007). Modern Sociological Theory. Publisher Reader achievement; First Edition: December 2007

Ratna, N.K. (2005). Literature and Cultural Studies: Representations Fiction and Fakta. Yogyakarta: Student Library.

Sedyawati, E. (1986). "Taxi as One of Cultural Expressions"in the Elementary Knowledge and Some Problems Dance Dance Jakarta: Directorate of Art. Jakarta Arts Development Project, Ministry of Education and Culture, Indonesia;

Soebadio, H. (1985). Cultural policy in Indonesia. Based on the Annual Reports of the Department of Education and Culture and material of the Centers and Directorates of the Directorate-General of Culture. Published in 1985 by the United Nations Educational, Scientific and Cultural Organization, Paris, France.

Soekmono. (1998). I. Introduction to the History of Culture Indonesia Yogyakarta: Canisius PT.

Spradley, J.P. (1997) Ethnographic Methods (Teijemahan). Yogyakarta: Tiara Discourse.

Suparlan, P. (1981). "Culture, Society and Religion: Religion as an Anthropological Research objectives"

Sutiyono. (2014). Developing HumanismThrough the Teaching and Learning of Traditional Arts in Indonesia. Asian Journal of Management Sciences and Education Vol. 3 (2) 201. April

Tengah. (2015). Borneo Tourism Office. Tourism Central Kalimantan. Online 